\title{
Development of Information System Application for Final Examination Industrial Engineering Department Univet Sukoharjo
}

\author{
Ainur Komariah \\ Universitas Veteran Bangun Nusantara \\ Sukoharjo, Indonesia \\ ainurkomariah@yahoo.com
}

\author{
Amin Multolib \\ UniversitasVeteran Bangun Nusantara \\ Sukoharjo, Indonesia \\ Aminmultolib@gmail.com
}

\author{
Darsini \\ Universitas Veteran Bangun Nusantara \\ Sukoharjo, Indonesia \\ darsini@gmail.com
}

\begin{abstract}
Information technology has an important role to improve the performance an organization. Industrial Enginering Department of Engineering Faculty, Veteran Bangun Nusantara University of Sukoharjo still uses the manual method withMicrosoft Excel to process the information system for Final Examination. The information system is needed to assist the lectures in courses managing process, the lectures data, the students grade, quickly and accurately. This research aims to develop the information system design application for the Final Examination at Industrian Engineering Study Program. This applications are made by using XAMPP program. Data collection is carried out by observation, interviews, literature studies, and searching for procedure documents for the Final Examination used in the Faculty of Engineering. The results of this study are the design of Final Examination System Application. The inputs are student data, course data, course data taken by students, lecture data, student grades data. The outputs of this application are the data of course participants, the number of course participants, courses conducted in the semester, courses conducted by each lecturer, and the student grades in each course taken.
\end{abstract}

Keywords-application, development, final exam, information system.

\section{INTRODUCTION}

The use of information technology has been used in all fields of industry. The ease gained through the use of information technology can improve work productivity. In addition to supporting the decision-making process, information systems can also help to coordinate, to monitor, to analyze the problems, to delineate complex things and to create new products [1]. The involvement of information systems can provide a positive contribution to the progress of the company's operational implementation [2]. The concrete results can be seen clearly from the expenditure, the efficiency achieved, and the satisfaction of external and internal participant.

The use of systems on computers can used in various fields such as economics, administrative education, and so on [3]. In the administration, for example in the campus environment or referred the Academic information system. The academic information systems are specifically designed to meet the needs of universities that want computerized education services to improve the performance, service quality, competitiveness and the quality of the human resources.
The development of Academic information systems is carried out continuously and intensively, following the development of technology and the basic needs of universities, in order to increase the ability of Academic information systems continued. The academic information systems can assist you to managing the data of student value, courses, teaching staff data (lecturers) and faculty / department administration which are still manual to work with the help of software to be able to streamline the time and to reduce the operating costs [4].

Veteran Bangun Nusantara University of Sukoharjo is a university located in Sukoharjo. The Industrial Engineering Study Program of Engineering Faculty is one of the Study Programs owned by Veteran Bangun Nusantara University of Sukoharjo. The Administrative activities in the Industrial Engineering Study Program are still manual so that the administrative staff and students are less comfortable and the administration process is too long. The number is not appropriate between registrants and the reality that is calculated and the difficulty of recapping the number of test participants in each subject.

Based on this background, the research was carried out with the aim to produce the design of the semester final exam information system application for Industrial Engineering Study Program. This application is expected to help the administration system in the Industrial Engineering Study Program. With this application is expected to be able to streamline time and reduce operating costs.

\section{METHODS}

\section{A. Object}

The object of this study is the process of conducting the semester exam and the process of the Study Result Card $(K H S)$ in the Industrial Engineering Study Program of Engineering Faculty, Veteran Bangun Nusantara University of Sukoharjo.

\section{B. Materials and Tools}

The tool that is used in this research is the developer Visual Basic 2008 and the My SQL Server database. The material that used in this research is the name of the student, the student's NIM, the name of the lecturer, the name of the course, and the number of credits. 


\section{Data Collections}

Data collection methods are carried out by looking for data regarding matters relating to records and documents directly from the source such as the name of the student, the name of the lecturer, the name of the course, System Credit Semester, and so on. This method is used to obtain the Academic supporting data to assist the research process.

\section{Technique of Collecting Data}

Technique of collecting data in this research are using Visual Basic 2008 applications and My SQL Server Database. This application is expected to solve the problem of academic information systems in the Industrial Engineering Study Program.

\section{RESUlt AND DisCUSSION}

\section{A. Planning System}

Design and plan contain of the data needed in making SIM program (Student Information System) for the researchers to know the processes needed in making the system.

Making information systems Students in registering for the Student Exams and Card Study Results (KHS) Industrial Engineering Study Program of Engineering Faculty, Veteran Bangun Nusantara University of Sukoharjo are made using Visual Basic and the My SQL Server data base. By using this software is expected to help the performance of employees in the Industrial Engineering Study Program of Veteran Bangun Nusantara University of Sukoharjo.

\section{B. The Data Flow}

1) Hierarchy

In this hierarchy database model is a data model which is the data arranged with a data tree structure or often known as one to many. Below is a picture of the student information system hierarchy model which can be seen in Figure 2.

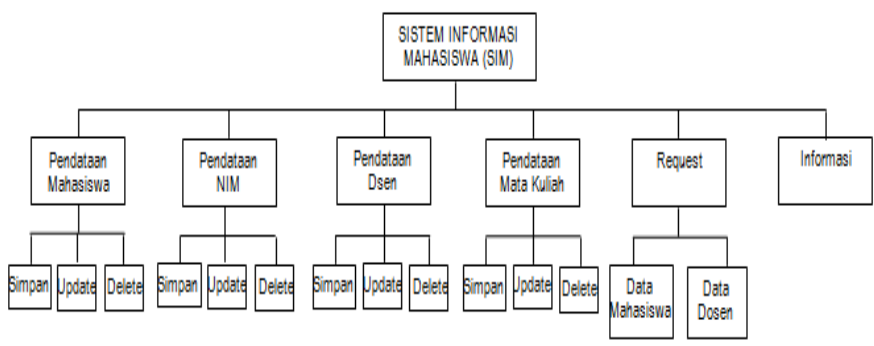

Figure 2. Hierarchy

\section{2) Data Flow diagrams (DFD)}

Data Flow Diagrams are models that describe the system as a network between functions that are interconnected with the flow and storage of data. DFD is often used to describe an existing system or a new system that will be developed logically without considering the physical environment where the data will be stored. Analysis of Data Flow Diagrams in the Industrial Engineering Study Program can be seen in Figure 3 to Figure 6.
3) DFD level 1 programming flow

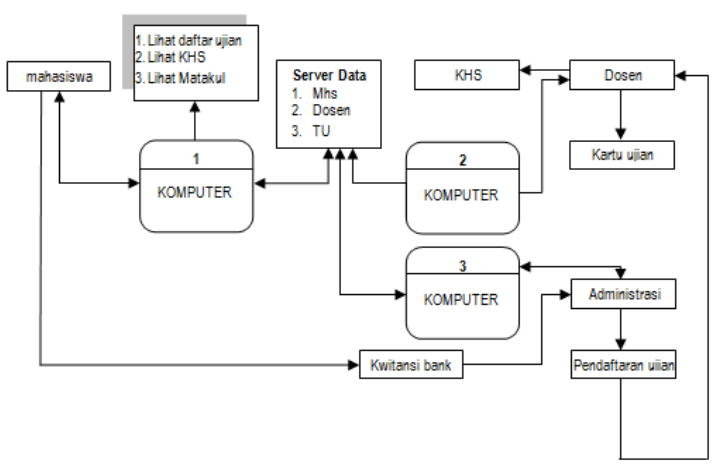

Figure 3. Program making flow

In Figure 3, it is explained about the flow of programming, where computer 1 , computer 2 , computer 3 are interconnected. Which will be connected to a data server that can be seen by students, lecturers, and administration. In the flow of making this program there are three admin who have different tasks. Students can only see, lecturers input data and print, administration only prints.

4) DFD level 2 processes student data input

Admin can save, update student data, and delete student data. This can be seen in Figure 4.

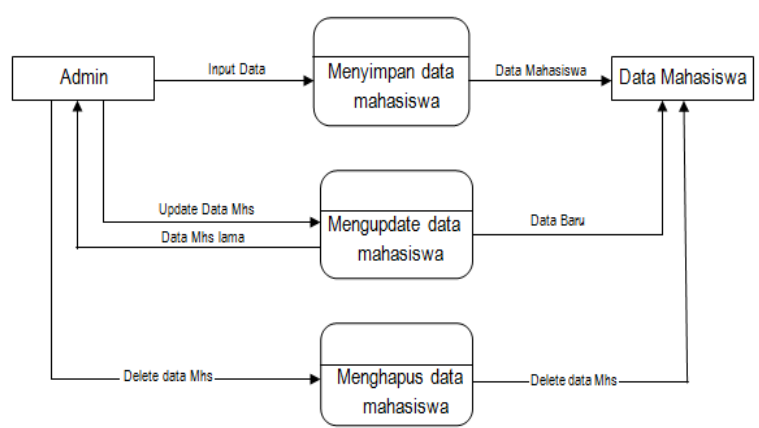

Figure 4. Process of inputting student data

5) DFD level 3 input process for lecturer data

In Figure 5, the lecturer data input process can be explained that the admin can store the lecturer data, update, and delete lecturer data.

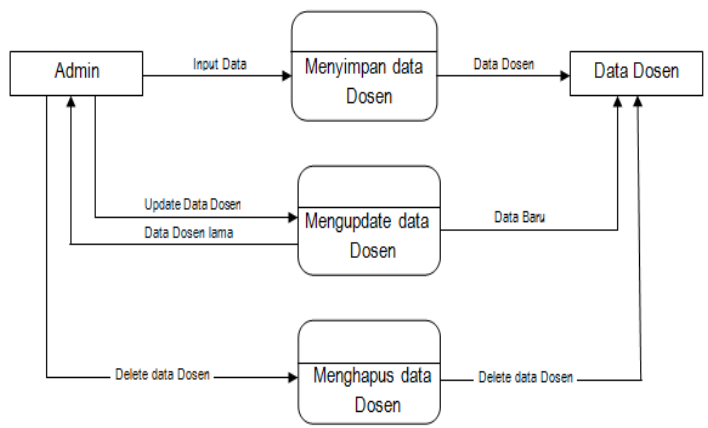

Figure 5. Process of inputting lecturer data 
6) Level 4 DFD The process of inputting courses

In DFD Level 4 this describes the process of inputting courses. At level 4, admin can store course data, update course data, and delete course data.

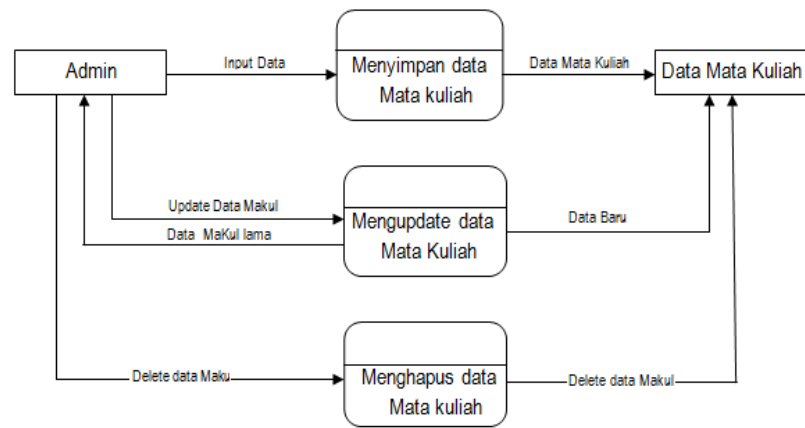

Figure 6. Process of inputting courses

\section{Data Modeling}

Data modeling is part of system design that contains fields needed by a database to run program applications that have been created. Data modeling can be said as an explanation of the fields filed in the database.

By using data modeling, the analysis system can define the data flowing in the system completely. Data modeling is based on the data flow in the flow diagram. Data flows and flow diagrams are global only addressed the name of the data flow only. The data related to the semester exam registration information system at Univet Bantara Sukoharjo Industrial Engineering Study Program can be seen in Figure 7.

In Figure 7, it can be explained that in this data modeling there are 6 inputs namely: profile of the institution, master lecturer, course, student, master login data. Here later between students, master lecturers, courses must have a login password which will be created by the login data master.

\section{Database Design}

In the construction of this system the database is used to store the data needed. File structure is a sequence of contents or data items that are in the database file. This structure design is intended to be able to conduct data search activities to facilitate system work. The file structure contained in the computerized semester exam registration information system can be shown in Table 1. until Table 5.
TABLE 1. DATA TABLE OF INSTITUTIONS

\begin{tabular}{llcc}
\hline \multicolumn{1}{c}{ Field } & Type Data & \multicolumn{1}{c}{ Key } & Explanation \\
\hline Institutions & Tinyint & Primary Key & Not Null \\
Faculty & Varchar & & Not Null \\
& $(14)$ & & \\
Study & Varchar & & Not Null \\
Program & $(30)$ & & Not Null \\
Address \& & Tinyint & & \\
Phone & & & \\
\hline
\end{tabular}

TABLE 2. LECTURER DATA TABLES

\begin{tabular}{lccc}
\hline \multicolumn{1}{c}{ Field } & Type Data & Key & Explanation \\
\hline Status & Varchar (20) & Primary Key & Not Null \\
Lectures & Varchar (35) & & Not Null \\
NIP & Varchar (30) & Primary Key & Not Null \\
Class & Varchar (11) & & Not Null \\
Study & Varchar (30) & & \\
Program & & & \\
\hline
\end{tabular}

\begin{tabular}{lccc}
\hline \multicolumn{1}{c}{ Field } & Type Data & Key & Explanation \\
\hline NIM & Varchar (30) & $\begin{array}{c}\text { Primary } \\
\text { Key }\end{array}$ & Not Null \\
Name & Varchar (35) & & Not Null \\
Hometown & Varchar (10) & & Not Null \\
Date of Birth & Varchar (11) & & Not Null \\
Generation & Varchar (22) & & Not Null \\
Majors & Varchar (30) & Not Null \\
Guardian & Varchar (24) & Not Null \\
Lecture & & & \\
\hline
\end{tabular}

TABLE 4. TABLE OF COURSE DATA

\begin{tabular}{llll}
\hline \multicolumn{1}{c}{ Field } & \multicolumn{1}{c}{ Type Data } & \multicolumn{1}{c}{ Key } & Explanation \\
\hline MK Code & Tinyint & Foreign & Not Null \\
& & Key & \\
MK Name & Varchar (35) & & Not Null \\
MK Groups & Varchar (12) & & Not Null \\
SKS & Varchar (5) & Primary & Not Null \\
& & Key & \\
$\begin{array}{l}\text { Requirements } \\
\text { Lecture }\end{array}$ & Varchar (15) & & Not Null \\
\hline
\end{tabular}

TABLE 5. LOGIN DATA TABLE

\begin{tabular}{llll}
\hline \multicolumn{1}{r}{ Field } & Type Data & \multicolumn{1}{c}{ Key } & Explanation \\
\hline Kode MK & Varchar (15) & $\begin{array}{l}\text { Foreign } \\
\text { Key }\end{array}$ & Not Null \\
Username & Varchar (30) & & Not Null \\
Pasword & Text & $\begin{array}{l}\text { Primary } \\
\text { Key }\end{array}$ & Not Null \\
Status & Varchar (20) & & Not Null \\
\hline
\end{tabular}


now after the existence of this system can be done computerized. This system is expected to help the work of the Industrial Engineering Study Program of Veteran Bangun Nusantara University of Sukoharjo is more efficient.

\section{ACKNOWLEDGMENT}

This research supported by Universitas Veteran Bangun Nusantara Sukoharjo.

\section{REFERENCES}

[1] Laudon, K.C dan Laudon, J.P. Management Information System: Managing The Digital Firm, 12th Edition. Prentice Hall: USA, 2012.

[2] Oktavia, Tanty. Peran serta strategi sistem informasi terhadap keberhasilan penerapan teknologi informasi perusahaan. Jurnal Comtech Vol 2. No 1 Juni 2011.

[3] Suteki, "sistem-informasi-akademik," URL www.sisteminformasi.instablogs.com. Diakses online

[4] Hidayatullah, Priyanto. Visual Basic.Net Membuat Aplikasi Database dan Program Kreatif.Yogyakarta:Informatika,2012. 